LACAN WITH THE PHILOSOPHERS 
This page intentionally left blank 


\title{
Lacan with the Philosophers
}

\author{
RUTH RONEN
}

Translated from Hebrew by Michal Sapir

UNIVERSITY OF TORONTO PRESS

Toronto Buffalo London 
(C) University of Toronto Press 2018

Toronto Buffalo London

utorontopress.com

Printed in the U.S.A.

ISBN978-1-4875-0281-2

()

Printed on acid-free, $100 \%$ post-consumer recycled paper with vegetable-based inks.

\section{Library and Archives Canada Cataloguing in Publication}

Ronen, Ruth, 1958-

[Lacan im ha-philosophim. English]

Lacan with the philosophers / Ruth Ronen ; translated from

Hebrew by Michal Sapir.

Translation of: Lacan im ha-philosophim.

Includes bibliographical references and index.

ISBN 978-1-4875-0281-2 (hardcover)

1. Lacan, Jacques, 1901-1981. 2. Psychoanalysis and philosophy.

3. Philosophers, Ancient. I. Title. II. Title: Lacan im ha-philosophim.

English.

BF109.L32R6613 $2018 \quad$ 150.19’5092 C2017-906772-9

This book was published with the support of the Israel Science Foundation (ISF).

University of Toronto Press acknowledges the financial assistance to its publishing program of the Canada Council for the Arts and the Ontario Arts Council, an agency of the Government of Ontario.

Canada Council for the Arts
Conseil des Arts du Canada 